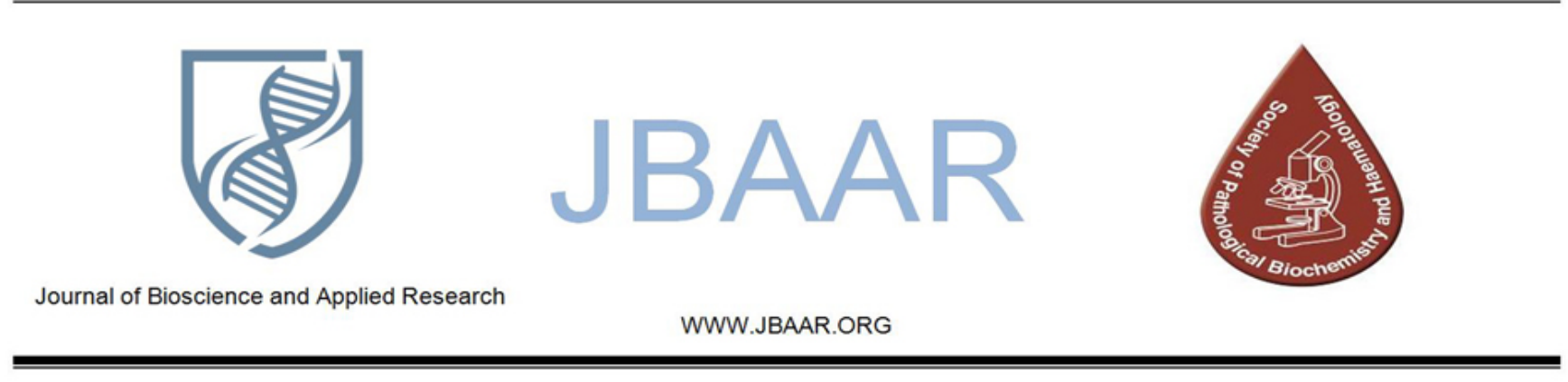

\title{
Pomegranate peel Extract Protects Cadmium-induced nephrotoxicity in albino mice
}

\author{
Amal A. El-Daly \\ Zoology Department, Faculty of Science, Benha University, Benha, Egypt \\ (Corresponding author e-mail. ml_eldaly@yahoo.com)
}

\begin{abstract}
Cadmium chloride $\left(\mathrm{CdCl}_{2}\right)$ is a toxicant heavy metal and kidney function through significant decrease in urea, displays adverse properties in humans creating public creatinine and BUN, reduced the level of serum MDA as health risks. Pomegranate (Punica granatum L.) is widely lipid peroxidation marker and restored the altered known as antimicrobial and antioxidant. This study antioxidant system activity. It was concluded that Cd investigated the cadmium induced structural effects in mice induced nephrotoxicity at a dose level $2 \mathrm{mg} / \mathrm{kg}$ b.w. in and evaluated the beneficial effect of alcoholic extract of $P$. mice. The PPE may be involved in the protection of granatum fruit peel (PPE) to protective $\mathrm{CdCl}_{2}$ toxicity displayed by $\mathrm{CdCl}_{2}$ induction attributed to the high nephrotoxicity. Animals were divided into 4 groups; group antioxidant capacity.

1: control, group 2: given 25ml/kg PPE, group 3: given Keywords: Cadmium chloride, nephrotoxicity, $\mathrm{CdCl}_{2}$ at a dose level of $2 \mathrm{mg} / \mathrm{kg}$ and group 4: given $\mathrm{CdCl}_{2}$ pomegranate, histopathology, immunohistochemistry, and PPE. The animals were given the previous treatment ultrastructure, antioxidant.

daily for 14days. $\mathrm{CdCl}_{2}$ intoxication led to obvious many histopathological alterations in kidney glomeruli accompanied with wide and congested blood vessels, renal tubules missed their distinct form with cytoplasmic vacuolation of their epithelial cells and pyknotic nuclei and leucocytes cells infiltration in the intertubular spaces. On the other hand, the immunohistochemical staining of antiapoptotic Bcl-2 and $\alpha$-smooth muscle actin ( $\alpha$-SMA) expressions were positive after $\mathrm{CdCl}_{2}$ exposure compared with the control group. Ultrastructure observations revealed thickening of the glomerular basement membrane and fusion of the podocytes foot processes, tubular epithelial cells vacoulation with pyknotic nuclei, perforation and vacoulation of mitochondria, deterioration of endoplasmic reticulum, and increase of lysosomes. $\mathrm{CdCl}_{2}$-exposure accompanied by increased level of serum urea, creatinine and blood urea nitrogen (BUN) as well as significant increase in malondialdehyde (MDA) besides decreased of the total antioxidant capacity (TAC) level. In contrast, coadministration of PPE plus $\mathrm{CdCl}_{2}$ ameliorated these parameters around the normal levels. It contributed the improvement by the histological, ultrastructure and decreased Bcl-2 and $\alpha$ smooth muscle protein expression,

\section{Introduction}

Cadmium is a heavy metal with widespread industrial applications and well-known human carcinogens (Siddiqui, 2010 and Mohammad et al., 2013). Occupational exposure to Cd mainly occurs in factories that set of batteries and accumulators containing $\mathrm{Cd}$ as well as in mines and zinc processors (Madeddu et al., 2012). Nonetheless, around $80 \%$ of dietary Cd intake comes from cereals, potatoes and vegetables (Galal-Gorchev, 1993 and Moy, 1993).The toxicological responses to exposure of cadmium include kidney, liver and stomach damage, respiratory and bone disease and neurological disorders (Nordberg et al., 2002, Koyu et al., 2006 and Schöpfer et al., 2010). Therefore, it associate with the liver and kidney tissue (Siddiqui, 2010 and Mohammad et al., 2013), breast cancer (Nagata et al.,2013 and Itoh et al., 2014), cancers of the bladder, stomach, and pancreas (Waalkes et al.,2003 and Benbrahim-Tallaa et al., 2009) and cardiovascular dysfunctions (Tellez-Plaza et al.,2008). Cadmium-mediated toxicity is thought to involve the induction of apoptosis (Yuan et al., 2012) and carcinogenesis involves multiple mechanisms including DNA strand breakage and inhibition
\end{abstract}


of DNA repair (Zhou et al., 2013). Moreover, Cadmiuminduced peroxidation caused the release of free oxygen radicals (Llobert et al., 1998). These free radicals cause the stimulation and destruction of sensitive macromolecules and indeed tissues (Lafuente, 2000).

Pomegranate extract (PE) and its derivatives have been used to health benefits in a number of diseases. Edible parts of pomegranate fruit represent $52 \%$ of total fruit weight, comprising 78\% juice and 22\% seeds (Tsuda et al., 2002). $\mathrm{PE}$ is a rich source of potent polyphenolic and flavonoid antioxidants. These polyphenolic flavonoid antioxidants enhance the biological actions of naturally produced nitric oxide (NO) in vivo, stabilize $\mathrm{NO}$ and prolong cellular concentration of NO by protecting it against free radical destruction, e.g. by reactive oxygen species (Ignarro et al., 2006).

Recently, it has been shown that pomegranate possesses several pharmacological activities as antioxidant (Viladomiu et al., 2013) anticarcinogenic (Afaq et al., 2010) and anti-inflammatory properties (Colombo et al., 2013). Moreover, pomegranate peel has been investigated as an antidiabetic, antiparasitic agent and to heal gastrointestinal disorders such as aphthae, diarrhea, and ulcers (Viladomiu et al., 2013). Many investigators have reported that pomegranate and its derivatives have free radical scavenger and potent antioxidant activity (Selvam, 2000 and Chen et al., 2003). It has also been shown that pomegranate can suppress nuclear factor- $\kappa \mathrm{B}(\mathrm{NF}-\kappa \mathrm{B})$ activation through a novel mechanism in vascular endothelial cells (Itoh et al., 2005 and Ozbek et al., 2009), reduce oxidative damage by preventing the excessive generation of free radicals (Al Olayan et al., 2014), preventing widespread range of many diseases such as cancer, diabetes, cardiovascular disease (Afaq et al., 2010, Aviram and Rosenblat, 2012 and Jain et al., 2012). Pomegranate can induce its beneficial effects through the influence of its various bioavailable constituents and metabolites on gene expression (Zarfeshany et al., 2014). The present study is undertaken to determine the possible inhibitory effects of PPE against $\mathrm{CdCl}_{2}$-induced oxidative stress and renal injury of adult albino mice using light, transmission electron microscope and biochemical approach.

\section{Materials and Methods Experimental animals:}

Adult male albino mice (Mus musculus) weighing 20 \pm 5 g was purchased from Animal House Colony of the National Research Centre, Cairo, Egypt. The animals were housed in plastic cages $(40 \times 30 \times 16 \mathrm{~cm})$ and kept in the laboratory under constant temperature $\left(25 \pm 2^{\circ} \mathrm{C}\right)$ with a $12 \mathrm{~h}$ light/dark cycles and a relative humidity of $50-60 \%$ for at least one week before the period of the experimental work. They were maintained on a standard rodent diet. Water was available ad libitum.

Materials used:

1-Cadmium chloride $\left(\mathrm{CdCl}_{2}\right)$ :

Cadmium chloride was obtained from Sigma Chemical Company, ARC, Egypt. It used in a dose level equal
$2 \mathrm{mg} / \mathrm{kg}$ b.w. /day for consecutive 14 days. Lethal dose for $\mathrm{CdCl}_{2}$ in mice is $6.7 \mathrm{mg} / \mathrm{kg}$ according to Ali, (2012).

2- Pomegranate peel extracts (PPE):

The present extract (PPE) was prepared when fruit was purchased from the local market at Zagazig, Egypt and prepared after (El-Toumy and Rauwald, 2002). One kilogram fresh peel were cut into small pieces, mixed in a mechanical blender with $80 \%$ methanol and leaved at room temperature for $72 \mathrm{~h}$. The extract was filtered through a filter paper and concentrated to dryness under reduced pressure in a rotary evaporator at $40-50^{\circ} \mathrm{C}$ in order to reduce the $\mathrm{MeOH}$ extract volume. The obtained pomegranate peel extract was stored at $-20^{\circ} \mathrm{C}$ until conduct. Each animal in the present study was orally given $0.25 \mathrm{ml}$ of the final $\mathrm{MeOH}$ extract by gastric intubation. This dose of pomegranate was selected according to Moghaddam et al. (2013).

\section{Experimental design:}

Mice were randomly divided into four equal groups, ten in each. The animals of each group were housed in a separate plastic cage.

Group I: control animals were orally given $0.5 \mathrm{ml}$ of distilled water for 14 days and were injected with a single dose of $0.25 \mathrm{ml}$ normal saline intraperitoneal (i.p.).

Group 2: Mice were orally given PPE by gastric intubation at a dose of $25 \mathrm{mg} / \mathrm{kg}$ b.w. for 14days.

Group 3: Animals were intraperitoneally (i.p.) injected with $\mathrm{CdCl}_{2}$ at a dose equal $2 \mathrm{mg} / \mathrm{kg}$ b.w. per day for consecutive 14 days

Group 4: Animals were administered $\mathrm{CdCl}_{2}$ and alcoholic pomegranate peel extract for 14days.

All the experiments were done in compliance with the guide for the care and use of laboratory animals (National Research Council, 1985). At the end of the experimental period, the mice were sacrificed. Blood samples were collected from the retroorbital venous plexus in centrifuge tubes and the serum was conserved at $-80^{\circ} \mathrm{C}$.

\section{Histopathological examination:}

Both the treated and control animals were killed by cervical disruption, quickly dissected and kidney was removed, fixed in $10 \%$ neutral buffered formalin , then processed for routine paraffin embedding. Paraffin sections were cut into 5 micrometers thick slices and stained with haematoxylin and eosin for light microscope examination. Other sections were processed for immunohistochemical study for expression of Bcl-2 and $\alpha$ smooth muscle actin. The slides were viewed and photographed by light microscopy.

\section{Immunohistochemical Analysis:}

\section{Bcl-2 staining:}

The production of the anti-Bcl-2 monoclonal antibody designated 124 (Dr. David Mason, Oxford University) has been previously described by the method used by Pezzella et al. (1990). Briefly, unstained sections from representative paraffin-embedded tissue samples were deparaffinized, rehydrated, and preincubated with $1 \% \mathrm{H}_{2} \mathrm{O}_{2}$ to abolish endogenous peroxidase activity. The sections were then incubated for 30 minutes with the anti-Bcl-2 
monoclonal antibody and then sequentially incubated with biotinylated goat anti-mouse immunoglobulin (Jackson Immunoresearch Laboratories,Inc., West Grove, PA) and horseradish peroxidase conjugated streptavidin (Jackson Immunoresearch Laboratories, Inc.) for 40 minutes each with brief phosphate-buffered saline washes between each step. Diaminobenzidine (DAB) was used as a chromagen followed by copper sulfate to darken the reaction product and absolute methanol to fix the precipitate. Finally, the sections were lightly counterstained with hematoxylin, dehydrated; cover slipped, and examined using a standard light microscope.

\section{Alpha-smooth muscle actin ( $\alpha$-SMA):}

Immunohistochemical stain for $\alpha$-SMA was performed according to Carey et al. (1992). The stained with the immunoperoxidase technique using a monoclonal anti- $\alpha$-SM-specific actin antibody (clone No. 1A4, lot No. 107F-4806, Sigma Chemical Co., St. Louis, Mo.) diluted 1:400 in phosphate buffered saline containing 3\% bovine serum albumin. Using a monoclonal anti- $\alpha$-SM-specific actin antibody (clone No. 1A4, lot No. 107F-4806, Sigma Chemical Co., St. Louis, Mo.) diluted 1:400 in phosphate buffered saline containing 3\% bovine serum albumin. The paraffin sections (7 um thick) deparaffinized, hydrated and washed in phosphate buffered saline for 5 minutes. Quenching of endogenous peroxidase activity was achieved by incubating the sections for 30 minutes in $0.3 \% \mathrm{H}_{2} \mathrm{O}_{2}$ in methanol. After washing in phosphate buffered saline, the sections were incubated with normal horse serum for 20 minutes. Thereafter, the sections were incubated for 90 minutes with the primary antibody. Sections were rinsed in phosphate buffered saline and incubated with anti-mouse IgG biotinylated antibody for 30 minutes. After washing in phosphate buffered saline, the sections were incubated with the avidin-biotinylated horseradish peroxidase complex (Vectastain ABC reagent, Vector Laboratories, Inc., Burlingame, Calif.) and exposed for 5 minutes to $0.1 \%$ diaminobenzidine tetrahydrochloride and $0.02 \% \mathrm{H}_{2} \mathrm{O}_{2}$. The sections were washed in tap water and counterstained with hematoxylin. As negative controls, the primary antibody was omitted. No staining occurred in any control section.

Transmission electron microscopy (TEM):

The kidneys were cut into small pieces of 1-2 mm size and fixed in $2.5 \%$ glutaraldehyde in $0.1 \mathrm{M}$ cacodylate buffer at $\mathrm{pH} 7.4$ for $24 \mathrm{~h}$. Specimens were washed in $0.1 \mathrm{M}$ phosphate buffer at $4^{\circ} \mathrm{C}$, then post fixed in $1 \%$ osmium tetroxide for $2 \mathrm{~h}$ at $4^{\circ} \mathrm{C}$. Specimens were dehydrated in ascending grades of ethyl alcohol then put in propylene oxide to prepare blocks embedded in Epon resin. Semithin sections $(1 \mu \mathrm{m})$ were stained with toluidine blue in borax and examined with light microscope. Ultrathin sections (50 $\mathrm{nm}$ ) were cut, mounted on copper grids and stained with uranyl acetate and lead citrate (Bancroft and Stevens, 1996) and examined and photographed with Jeol 1200 EX transmission electron microscope in the College of Medicine, Tanta University.

\section{Biochemical analysis:}

For biochemical study, blood samples were collected from animals after 14days of treatment. Sera were obtained by centrifugation of the blood sample and stored at $-80^{\circ} \mathrm{C}$ until assayed for the biochemical parameters. Renal function is assessed by serum urea, creatinine (SCR), and blood urea nitrogen (BUN) therefore reflects the glomerular filtration rate (GFR) renal impairment. Creatinine was estimated spectrophotometrically using the method of Young and Friedman (2001) in which creatinine in alkaline solution reacts with picrate to form a red complex. Serum creatinine and blood urea nitrogen (BUN) were determined using commercially available kits (Bioclin, Santa Coloma, Spain) following manufacturer's instructions.

Determination of oxidative stress markers and total antioxidant capacity in tissue homogenates:

For estimation of the oxidative stress, specimens from kidney tissue $(0.25$ g) were ice cooled, homogenized in $2.5 \mathrm{ml}$ phosphate buffer ( $\mathrm{pH} 7.4$ ), and then centrifuged at $3000 \mathrm{xg}$ for $15 \mathrm{~min}$ at $4^{\circ} \mathrm{C}$. The generation of reactive oxygen species (ROS) expressed as lipid peroxidation product (malondialdehyde; MDA) was evaluated in the resultant supernatant using commercially available kits (Biodiagnostics Co, Giza, Egypt) following manufacturer's instructions. The lipid peroxidation was estimated as the concentration of thiobarbituric acid reacts with malondialdhyde in acidic medium at temperature of $90^{\circ} \mathrm{C}$ for $30 \mathrm{~min}$. to form thiobarbituric acid reactive products the absorbance of the resultant pink product can be measured at 534nm. Lipid peroxidation was measured according to Ruiz-Larrea et al. (1994).

For estimation of the total antioxidant capacity (TAC), specimens from kidney tissue $(0.25 \mathrm{~g})$ were ice cooled, homogenized in $2.5 \mathrm{ml}$ phosphate buffer ( $\mathrm{pH} 7.4)$, and then centrifuged at $3000 \mathrm{xg}$ for $15 \mathrm{~min}$ at $4^{\circ} \mathrm{C}$. Malondialdehyde was evaluated in the resultant supernatant using commercially available kits (Biodiagnostics Co, Giza, Egypt) following manufacturer's instructions. The principal of this method depends on the reaction of antioxidants in the sample with a defined amount of exogenously provide hydrogen peroxide $\left(\mathrm{H}_{2} \mathrm{O}_{2}\right)$. The antioxidants in the sample eliminate a certain amount of the provided $\mathrm{H}_{2} \mathrm{O}_{2}$. The residual $\mathrm{H}_{2} \mathrm{O}_{2}$ is determined calorimetrically by the enzymatic reaction which involves the conversion of 3,5, dichloro-2-hydroxyl benzensulphate to a colored product.

Statistical analysis:

The results were expressed as mean \pm SD of different groups. Data were analyzed by using Student's t -test and homogeneity of variances (Levene test) using statistical program of social science (Excel) software for windows.

\section{Results \\ Histological results:}

Histological examination of the kidney of control mice revealed completely regular structures of the renal cortex which comprised renal corpuscles, proximal and distal convoluted tubules (Fig.1a). Interstitial space was devoid from any inflammatory variations. In a similar matching, no histological alterations were observed in animals treated with PPE (Fig.1b). While, examination of the kidney sections of mice treated with $2 \mathrm{mg} / \mathrm{kg} \mathrm{CdCl}_{2}$ for 14 days 
showed Malpighian corpuscles and renal tubules lost their normal pattern with degenerated epithelium. Glomerular (G) hyperatrophy with architectural complexity markedly increased with irregular capsular space (Fig. 1c and d). The tubular epithelia were detached from basement membrane, destruction of cytoplasm by means of vacuolation, the nuclei were pale or distorted as sign of pyknosis besides it protruded in the irregular lumen of the tubules. Dark elongated cells in the narrow interstitial tissue with enlarged and congested renal veins (C) were detected; cleft Malpighian corpuscles (G) with indented shaped, degenerated renal tubular epithelial cells with pyknotic nuclei and wide lumen were shown (Fig. 1d). The improvement of both glomeruli and the renal tubules after treating with $\mathrm{CdCl}_{2}$ and PPE $(25 \mathrm{mg} / \mathrm{kg}$ ) for 14days was exhibited (Fig. 1e and 1f). There was no congestion, no cellular proliferation while hyaline substance presented in the tubular lumen. Some glomeruli and renal tubules seemed as approximately nearly to control due to the protective effect of the extract.

\section{Immunohistochemical Results}

BCl-2:

Examination of kidney sections obtained from the control group stained with anti-apoptotic Bcl-2 antibody revealed little or slight immunoreactive cytoplasm in distal and the proximal tubular cells, glomeruli and interstitial (Fig. 3a). In contrast, $2 \mathrm{mg} / \mathrm{kg} \mathrm{CdCl}_{2}$ exposure for 14 days showed $\mathrm{Bcl}-2$ activity increased in some areas of the kidney tissue indicated by intense staining mainly in peritubular (Fig. 3b) in compared with control group. Combined treatment of $\mathrm{Cd}$ and $\mathrm{PPE}$ inhibited the expression of $\mathrm{Bcl}-2$ protein in the cytoplasm indicated as weak immunopositive reaction in kidney tubular epithelium (Fig. 3c).

\section{a-Smooth muscle actin:}

Kidney sections obtained from the control group and immunostained with $\alpha$ - SMA antibody revealed less protein expression detected in the smooth muscle of the vascular structures (fig. 3a) attended to the per tubular capillary. Similarly, no $\alpha$-SMA immunoreactivity was noticed in kidney of mice treated with PPE $(25 \mathrm{mg} / \mathrm{kg})$. In contrast, Cd-induced mice revealed intensely dark brown of accumulated protein expression correlated with densely packed smooth muscle network of connective fibres (fig. $3 b$ ) increased $\alpha$-SMA protein expression in compared to the control. The expression of this actin attended to the interstitial elastic vasculature was delayed after combination of $\mathrm{Cd}$ and PPE supplementation (fig. 3c) indicating that pomegranate was capable to restrict $\alpha$ - SMA expression in compared to the $\mathrm{Cd}$ induced animals.

\section{Ultrastructure Results:}

The ultrastructure of the proximal tubular cells in control mice displayed plentiful elongated and heavily packed apical microvilli extending within the tubular lumen besides regular basement cell membrane (BM).The cell cytoplasm contained basal oval heterochromatic nucleus with central dense nucleolus restricted by several elongated and oval mitochondria, apical lysosomes and rarely distributed short rough endoplasmic reticulum cisternae
(Fig. 4a). The administration of $\mathrm{Cd}(2 \mathrm{mg} / \mathrm{kg})$ for 14 days caused the proximal tubular cells to be with reduction of nucleus size through compacted heterochromatin as well as loss of nucleolus indicating necrosis, numerous dense lysosome bodies (Ly) and dilated rough endoplasmic reticulum (rER) (Fig. 4b). Moreover, the cytoplasm was granulated by numerous ribosomes and contains well ovoid small perforated with dense deposited bodies' mitochondria, irregular basement membrane as well as many vacuoles (Fig. 4c). The same figure exhibited loss of nucleolus besides increased distributed condensed nuclear heterochromatin through the nucleoplasm. A fragmented and detaching the apical microvilli and numerous vacuoles were observed (Fig. 4d). In combined $25 \mathrm{mg} / \mathrm{kg}$ of PPE and Cd-treated mice, the proximal tubular cells revealed oval euchromatic nucleus with peripheral electron-dense heterochromatin, numerous elongated and oval mitochondria, little perinuclear rER, no vacuoles and long microvilli indicated healthy formal cells as protected by PPE (Fig. 4e).

Figure (5a) represents the distal tubular cells of the control mice showed regular trilaminar basement membrane (BM) with parallel basal infoldings. Elongated shaped mitochondria and short rough endoplasmic reticulum cisternae were seen within the cytoplasm. The cell nucleus was spherical and centrally located contain peripheral heterochromatin and dense nucleolus. In Cdtreated mice, the distal tubular cells loss the basal infoldings with observable thickening of the basement membrane was detected (Fig. 5b). The cytoplasm enclosed many rounded degenerated mitochondria, little vacuoles and dilated rER. Obvious degeneration and disruption of the apical border of the cell membrane was seen. Other cells exhibited rarefied cytoplasm and pyknotic nucleus as well as more protruded apical cell membrane (Fig. 5c). The distal convoluted tubule of mice treated with $\mathrm{CdCl}_{2}$ and PPE improve of the cellular organelles and repaired the basal infoldings to be parallel with the elongated mitochondria (Fig. 5d). An ovoid nucleus as well as peripheral nucleolus was detected resembling usual event.

The renal corpuscle of control mice revealed normal ultrastructure; the glomerular capillary is normally surrounded by perforated tri-laminae glomerular basement membrane (GBM) (Fig.6a). The fenestrated endothelial cells (En) line the inner side of the capillary while the podocytes cover the outer one. The visceral epithelial cells or podocytes appeared with primary cytoplasmic foot processes that extended in capsular space and subdivided into many thin secondary cytoplasmic processes. A slim fenestrae or slits are observed among the podocyte foot processes (Fig. 6 b). The mesangial cells with small darklystained nuclei and little electron-dense cytoplasm are observed. The sections from animals treated with PPE showed regular renal corpuscle constructions (Fig. 6b).

Treatment with $\mathrm{CdCl}_{2}$ showed various alterations in the renal corpuscle as thickened of the glomerular basement membrane represented in obliterated fenestrae, ill-definite tri-laminae structure, and blend of the secondary foot processes of the podocytes in definite areas, increased 
electron lucent material in capsular space indicating precipitations of protein materials. The mesangial cells exhibited condensed and vacuolated nucleus and improved electron dense materials (Fig. 6c- e). In combined PPE and $\mathrm{CdCl}_{2}$ treated mice these variations in the glomerular components were restored as appeared nearly to the control. Normal capillary basement membrane and capsular space, mesangial cells component little fusion of the podocytes foot extensions were exhibited (Fig.6 f) signify a protective impact of PPE.
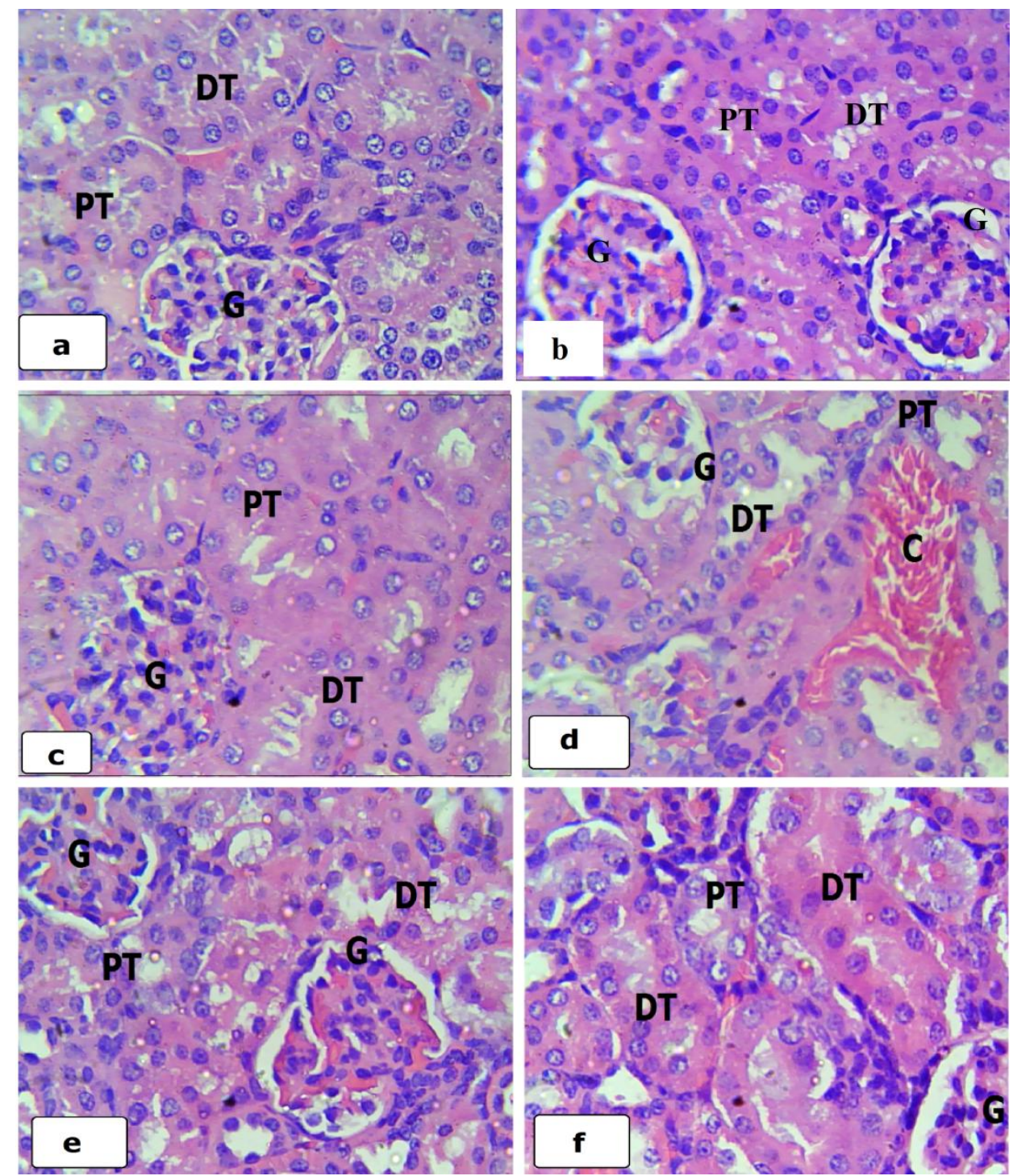

Fig. (1): kidney cortex section of control and $\mathrm{Cd} \mathrm{Cl}_{2}$ and/or PPE treated mice for 14day stained with H\&E showing; (a): Control mouse showing normal structure with no pathological changes appearance, normal glomeruli (G) and tubules, Bowmen's capsule with ordinary urinary space, proximal convoluted tubule(PT), distal convoluted tubular (DT). (b) PPE treated mouse showing normal glomerulus with no histological observed alterations or inflammatory cells. (c and d): $\mathrm{CdCl}_{2}$ treated mice displayed disorganization of PT and DT cells with vacuolated cytoplasm and lysed nuclei with apparent desquamated from the basement membrane, hyaline material in the lumen. Hypertrophic proliferated glomeruli as well as narrow interstitial tissue were detected. Fine dotted granules were scattered all over the renal tubular cells. (d) Enlarged and congested renal capillary, indented shaped Malpighian corpuscles and degenerated renal tubular epithelial cells with pyknotic nuclei and wide lumen was shown. (e and f) Renal tissue of mice treated with $\mathrm{CdCl}_{2}$ and pomegranate displayed improvement of glomeruli (G) and the renal tubules. No congestion, no cellular proliferation while hyaline substance still in the tubular lumen. Some glomeruli and renal tubules seemed as approximately nearly to control, (400 $\mathrm{X})$. 


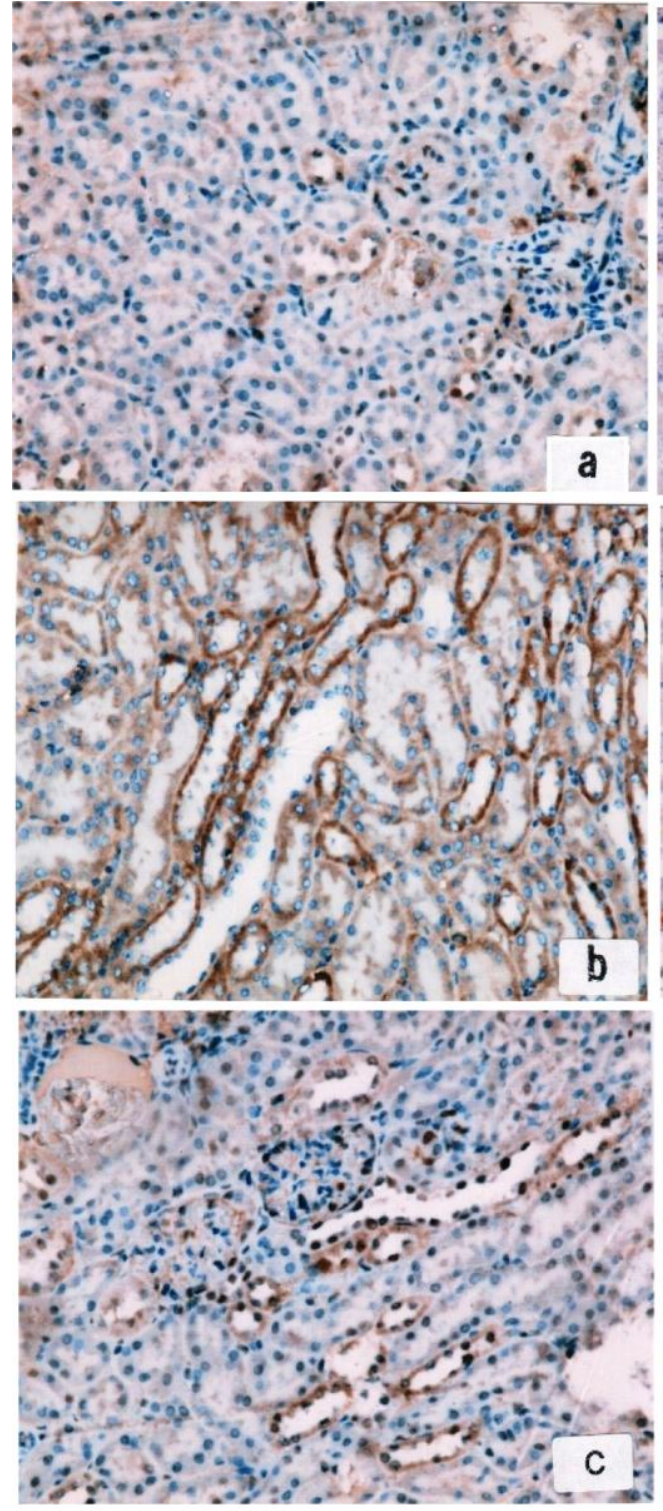

Fig. (2)
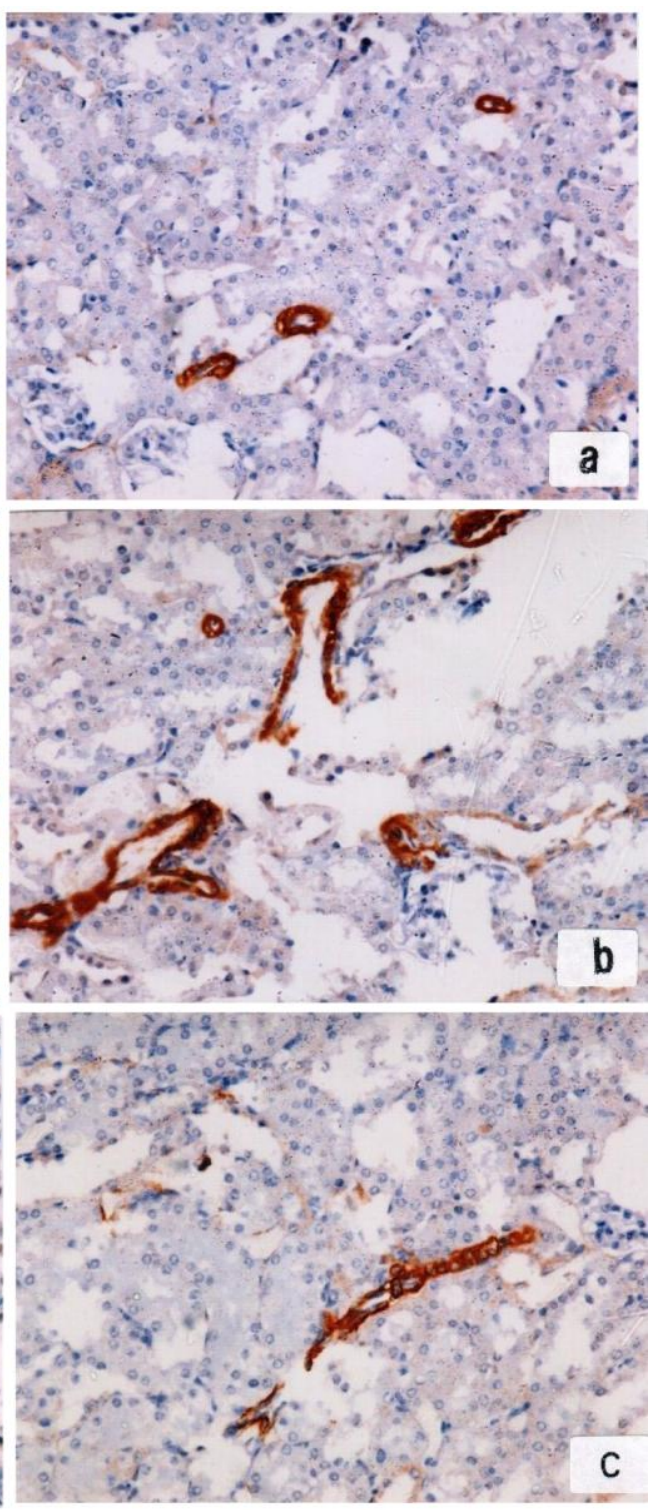

Fig. (3)

Fig. 2: kidney cortex section of control and $\mathrm{Cd} \mathrm{Cl}_{2}$ and/or PPE treated mice for 14day preserve an immunohistochemical Bcl-2 expression displaying; (a) little or negative immunoreactivity in cytoplasm of distal and the proximal tubular cells, glomeruli and interstitial tissue. (b) Kidney of $\mathrm{CdCl}_{2}$ treated group preserve high intensity of Bc1-2 immunopositive expression in the cytoplasm of tubular epithelial cells and interstitial tissue in compared with controls. (c): combined treatment of $\mathrm{Cd}$ and PPE exhibiting reduction or weak immunoexpression of Bcl-2 protein in the cytoplasm tubular epithelium compared to $\mathrm{CdCl}_{2}$ treated kidney, (400 X).

Fig. 3: kidney cortex section of control and $\mathrm{Cd} \mathrm{Cl}_{2}$ and/or PPE treated mice for 14day presenting an immunopositive $\alpha$ SMA expression revealed; (a) control group indicated slight $\alpha$-SMA protein expression within vascular smooth-muscle of the kidney tissue. (b) $\mathrm{Cd} \mathrm{Cl}_{2}$ treated mice revealed high level overexpression of $\alpha$-SMA as dark brown stain indicating activation of myofibroblasts development and fibrotic response in the renal capillaries. (c) combined treatment of $\mathrm{CdCl}_{2}$ and PPE exhibiting little stain of immunopositive $\alpha$-SMA expression protein indicate that PPE has proficient to repair the injury by Cd, (400 X). 


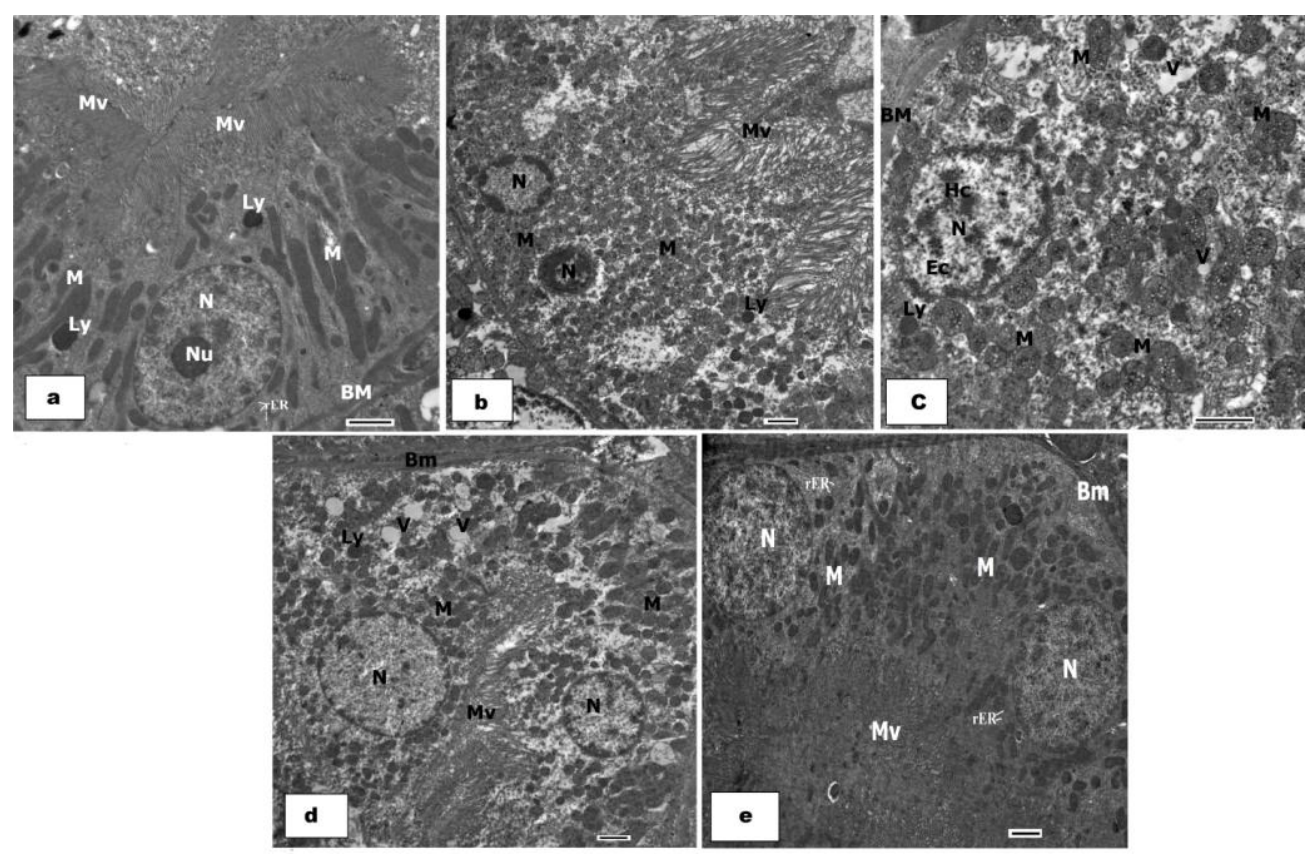

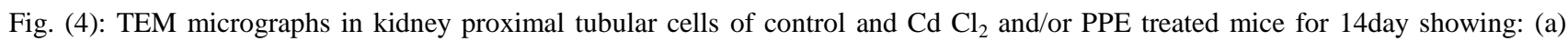
control kidney displayed regular basement membrane (BM), the cell has large oval basal heterochromatic nucleus (N), central nucleolus (Nu), several elongated and oval basally arranged mitochondria (M), lysosomes(Ly) and few short rough endoplasmic reticulum cisternae (rER).Numerous long microvilli (Mv) are seen. (b, c and d): PCT of Cd-treated kidney displaying parts of three neighboring cells with reduction in nucleus size with compacted heterochromatic nucleus $(\mathrm{N})$, as well as loss of nucleolus and numerous dense lysosome bodies (Ly), multiple degenerated mitochondria (M), vacuoles (V), and apical microvilli (Mv). The cells rest on thin basal lamina (arrow). (c): Another TEM of the same treatment showing granulated cytoplasm by numerous ribosomes, small ovoid and perforated mitochondria (M) with dense deposits, irregular basement membrane in addition to many vacuoles (V). (d) showing fragmented and detaching apical microvilli plus numerous vacuoles. (e) Combined Cd and PPE-treated mice, PCT cells revealed improved organelles; oval euchromatic nucleus with peripheral electron-dense heterochromatin, numerous elongated and oval mitochondria (M), tiny per nuclear rER, no vacuoles and long microvilli (Mv). (Scale bar $=2 \mu \mathrm{m})$.

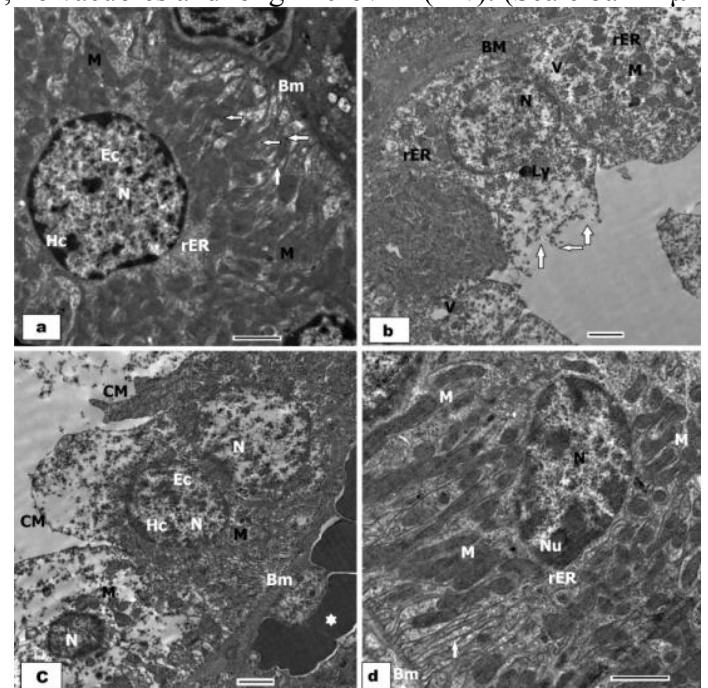

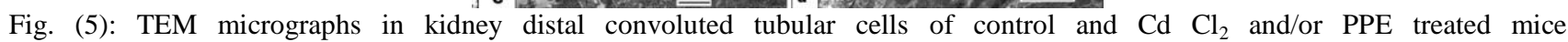
for 14day viewing: (a) kidney of control animal presenting regular trilaminar basement membrane (BM) with parallel basal infoldings (arrow) enclosed elongated mitochondria $(\mathrm{M})$ and small rough endoplasmic reticulum cisternae (rER) within the cytoplasm. Spherical nucleus $(\mathrm{N})$ centrally located enclose peripheral heterochromatin $(\mathrm{Hc})$ and dense nucleolus. (Scale bar $=2 \mu \mathrm{m})$. (b and c) Cd-treated kidney; DCT shown thickening of the basement membrane (BM), vacuole (V), lysosome (Ly), loss the basal unfoldings, obvious cell membrane disruption (arrow). (c) displaying cell with rarefied cytoplasm and necrotic nucleus (N) besides additional two cells with protruded apical cell membrane (CM), mitochondria (M),. (d) DCT of kidney treated with combined $\mathrm{CdCl}_{2}$ and PPE revealing repaired the parallel basal infoldings reappearance of plentiful elongated and apical oval mitochondria $(\mathrm{M})$, an ovoid nucleus (N) as well as peripheral nucleolus $(\mathrm{Nu})$, (Scale bar $=2 \mu \mathrm{m})$. 

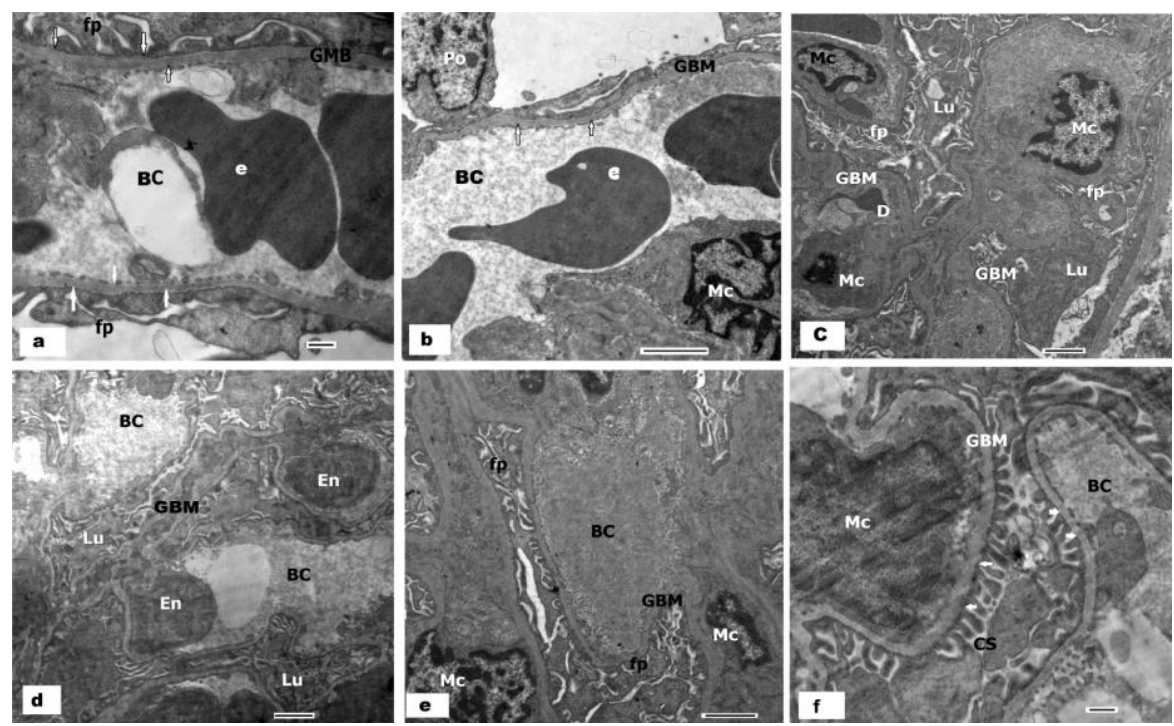

Fig. (6): TEM micrographs in kidney renal corpuscle of control and $\mathrm{Cd}^{\mathrm{Cl}_{2}}$ and/or PPE treated mice for 14day showing: (a) portion of renal corpuscle of kidney from control animal with normal glomerular capillary (C) enclosed by fenestrated (arrow) tri-laminae glomerular basement membrane (GBM), podocytes with thick primary foot processes (fp) that extended in urinary space. Barr $=500 \mathrm{~nm}$. (b)The section from animal treated with PPE showing regular renal corpuscle with usual glomerular basement membrane (GBM), erythrocyte (e) and masangial cell (Mc), Barr $=2 \mu$ (c - e) $\mathrm{CdCl}_{2}$ treated group displaying thickened of the glomerular basement membrane (GBM), ill-definite tri-laminae structure, and blend foot processes (fp), increased lucent material (Lu) beside compacted mesangial cell nucleus (Mc), Barr $=2 \mu$. (f) Combined $\mathrm{CdCl}_{2}$ and PPE treated mouse showing renovation of the glomerular components; capillary basement membrane and blood capillary (BC), lined endothelial cell (En), capsular space (CS) and mesangial cell (Mc) components. Little fusion of the podocytes foot processes (fp) extensions was exhibited, Barr $=500 \mathrm{~nm}$.

\section{Biochemical results:}

\section{Urea, creatinine and BUN:}

There are no significant differences in levels of urea, creatinine and BUN in both control and PPE groups. Animals treated with $\mathrm{CdCl}_{2}$ revealed significant increase in the levels of these parameters $(\mathrm{P}<0.05)$. On the other hand, treating animals with $\mathrm{CdCl}_{2}$ and PPE led to decrease in urea, creatinine and BUN indicating improved kidney function (Figs. 7 a). This levels was highly significant (P $<0.05$ ) after 14days of treatments.

\section{Lipid peroxidation marker (MDA):}

MDA an indicator of oxidative damage by ROS was significantly increased in mice tissue given $\mathrm{CdCl}_{2}$ (Fig.7b) when comparing with control group $(\mathrm{P}<0.05)$. As expected, animals treated with $\mathrm{CdCl}_{2}$ and PPE showed a significant decrease in MDA values compared with $\mathrm{CdCl}_{2}$ group indicated that PPE exhibited protective capacity against damaged induced by $\mathrm{CdCl}_{2}$.

\section{The total antioxidant capacity (TAC):}

The total antioxidant capacity in both control and PPE groups significantly increased in kidney tissue indicated high antioxidant capacity of PPE to stimulate the antioxidant factors. However, Fig.7c demonstrated that the effect of Cd for 14days decrease the renal tissue TAC significantly in animals treated with $\mathrm{CdCl}_{2}$.compare to control group. In contrast, $\mathrm{CdCl}_{2}$ and $\mathrm{PPE}$ treatment ameliorates the increased level of the total antioxidant capacity in kidney compared with Cd group indicated high capacity of PPE for creating antioxidant factors.

\section{Discussion}

The present study investigated the protective role of PPE on renal tissue damage after the induction of $2 \mathrm{mg} / \mathrm{kg}$ $\mathrm{CdCl}_{2}$ for 14 days in mice. The data demonstrated that the inducted kidney had higher structural and functional alterations through histological, ultrastructure beside higher tissue Bcl-2 and $\alpha$-SMA expression. Moreover, the results showed that kidney had higher serum urea, creatinine, and BUN and MDA levels and lower the ant-oxidative capacity level in tissue homogenate. PPE, on the other hand, squeezed the severity of injury, lower the concentration of these parameters and increased TAC. Pomegranate extract is rich in more potent antioxidants like the polyphenol and flavonoids compounds which dispose, scavenge, and suppress the formation of reactive oxygen species (ROS) and lipid peroxidation hence ameliorative nephrotoxicity. Moreover, the overproduction of ROS stimulates detrimental to kidney function and structure through the present results. Consequently, these ROS stimulated by Cd terminated pathological conditions both in humans and animals (Waisberg et al., 2003).

In the current study, many severe indications caused by $\mathrm{CdCl}_{2}$ induction for 14 days as enlarged and congested renal capillaries, enlarged and misshapen glomeruli. The renal tubular epithelial cells were deteriorated, or atrophied with dilatation in the subcapsular space. Signs of inflammation were revealed. 

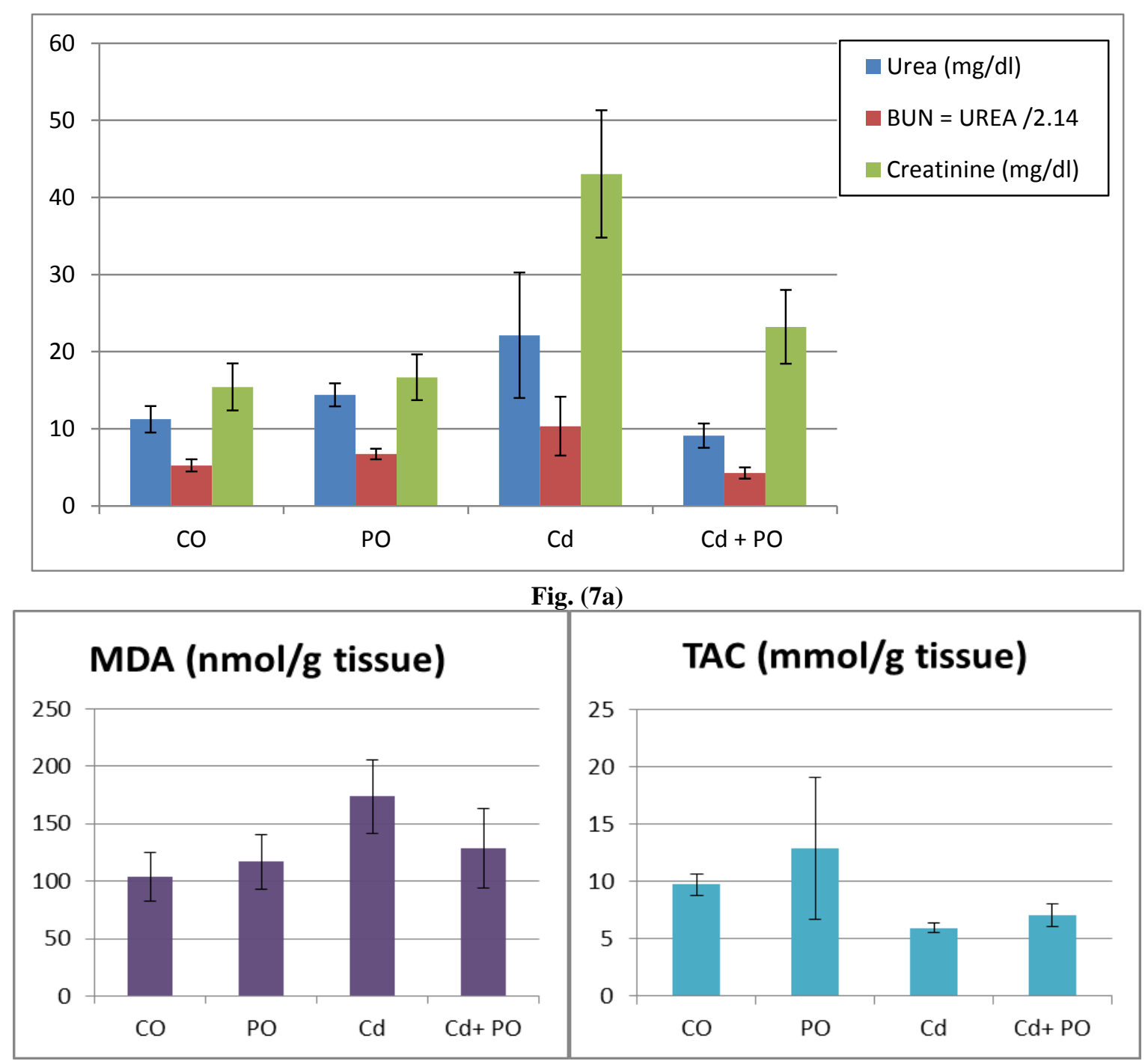

Fig. (7a)

Fig. (7a)

Fig. (7a-c): Histograms showing differences in levels of urea, creatinine, BUN, MDA and TAC in different experimental groups. Data are presented as the mean $\pm \mathrm{SD} .{ }^{*}$ Significantly at $\mathrm{P}<0.05$.

The tubular epithelia lining cells exhibited cytoplasmic destruction and vacuolation, pale or distorted nuclei as sign of pyknosis. This is consistent with the previous reports on histopathological effects of cadmium exposure on many organs of rats (El-Morsy et al., 2015). Accordingly, besides ROS mechanism and oxidative stress interconnected calcium balance may be destructive factors of the tissue and its cellular components when $\mathrm{Cd}$ injected to the animals. Görlach et al. (2015) reported that the dysfunction of the calcium ROS balance within the cellular organelles could result in novel therapeutic strategies for various diseases. Berridge et al. (2012) added that calcium $\left(\mathrm{Ca}^{2+}\right)$ is an important second messenger regulates a variety of cellular functions, including contraction, secretion, metabolism, gene expression, cell survival and cell death.

The present study exhibited a marked increase in the expression of the anti-apoptotic Bcl-2 protein in cadmiumexposed cells cytoplasm compared with unexposed cells.
This means an increase in anti-apoptotic gene expression that could explain the increased apoptosis impact of Cd on the cells. Moreover, this apoptotic mechanism may be defense state to combat the oxidative stress produced by resulted $\mathrm{CdCl}_{2}$ metallothionine harmfulness in the cells. Confirming this, it was reported by Gross et al. (1998) and Hsu and Youle et al. (1998) that Bcl-2 has been shown to interact with multiple proteins. Moreover, the Bcl-2 genes are important in renal cell survival, development, repair and regeneration (Gobe et al., 2000).

Furthermore, overexpression of $\alpha$-SMA protein in renal tissues associates with $\mathrm{Cd}$ induction identified activation of fibroblasts secreting actin and progressive of fibrosis. Moreover, $\alpha$-SMA may be a useful marker in the study of apoptosis induced by Cd. Templeton and Liu (2013)revealed that filamentous actin cytoskeleton is required to initiate apoptotic and apoptotic-like death as $\mathrm{Cd}^{2+}$ activate $\mathrm{Ca}^{2+}$ - dependent proteins that change the 
actin polymerization-depolymerization. Similar result below $\mathrm{CdCl}_{2}$ influence have been reported by several authors (Mahran et al., 2011 and El-Refaiy and Eissa, 2013) who observed that Cd displayed signs of interstitial fibrosis as increase of collagenous fibres in the liver and kidney. Correspondingly, increased $\alpha$-SMA expression in glomerular disease is marker of mesangial cell activation, hypertrophy rather than hyperplasia (Hugo et al., 1996 and Stephenson et al., 1998).

In the present study, numerous alterations were detected by the EM examination. Thickened glomerular basement membrane observed and may due to the excess of protein precipitation induced through the filtration barrier, so it impaired the glomerular filtration rate. Besides, cadmium chloride induced increased number of lysosomes, vacuoles and dilated rough endoplasmic reticulum. Thickened tubular basal lamina and destructed perforated mitochondria were achieved after Cd toxicity. This is agreement with the results obtained by Mahran et al. (2011) and El-Morsy et al. (2015) in kidney treated with $\mathrm{CdCl}_{2}$. Therefore, interconnected of ROS and intracellular calcium mechanism could imported these deterioration in the cellular organelles (Görlach et al., 2015). In the other hand, cadmium metallothionein (Cd-MT) that formed after absorption of $\mathrm{Cd}$ is a small molecular size, so it easy filtered through the glomerular membrane and taken by the renal tubular cells (Wong et al.,2012). Therefore, cadmium exposure causes glomerular damage and leading to albuminuria and a progressive decline in glomerular filtration rate (GFR) due to kidney function and protein excretion finally causing end-stage renal failure (Jarup, 2002, Johri et al., 2010 and Burser et al., 2016). Moreover, Johri et al., 2010 reported that Cd renal toxicity impaired reabsorption of low molecular weight proteins leading to tubular proteinuria as Cd accumulates Cd-MT, a good index of proximal tubular damage. Likewise, Cd-MT is degraded in endosomes and lysosomes releasing free Cd ions into the cytosol where it can generate ROS and activate cell death pathways. This could explain why the numerous lysosomes appear in the cytoplasm of the PCT and DCT in the present results.

Besides, the perforation and swelling of mitochondria in the current results may explained through either Bcl-2 overexpression that prevents mitochondrial permeability evolution and cytochrome c release and rupture of the outer mitochondrial membrane as revealed by Kowaltowski et al. (2000) and Orrenius et al. (2003) or increases the overall mitochondrial $\mathrm{Ca}^{2+}$-uptake capacity as reported by Murphy et al. (1996). Likewise, Wong et al. (2012) and Duchen (2000) reported that $\mathrm{Cd}$ exposure causes $\mathrm{Ca}^{2+}$ release from the endoplasmic reticulum and depolarization of the mitochondrial membrane potential as well as associated with oxidative stress which induces autophagy and apoptosis, leading to the death of mesangial cells. The authors added that the calcium-mitochondria-caspase signaling pathway contributes significantly to the Cdinduced death of mesangial cells.

Therefore, Cd oxidative stress may trigger pathological states lead to activation of many transcription factors, proteases, kinases, and Bcl-2-family proteins and their modulators through PCT and DCT alteration associated with Cd-induction in these results. This may be due to disturbances $\mathrm{Ca}^{2+}$-dependent and $\mathrm{Ca}^{2+}$-independent enzymes that have been involved in apoptotic DNA degradation (Robertson et al., 2000). Further, Zhou et al. (2013) observed decrease in DNA repair capacity coupled with changes in the cell cycle distribution and apoptosis after cadmium exposure that would create a microenvironment for genomic instability, leading to malignant transformation.

The results obtained here revealed elevated concentrations of serum urea and creatinine in $\mathrm{CdCl}_{2}$ treated mice. This rise may correlate with deficient of the filtration in the kidney hereafter in the glomerular filtration rate (GFR) as indicator of renal dysfunction provide a better index of tubular and glomerular disease. These results were in agreement with results obtained by many authors who observed increased serum urea and creatinine after rats treated with $\mathrm{CdCl}_{2}$ (Koriem et al., 2013 and Hussein et al., 2014).

On the other hand, there was an increased in the lipid peroxidation marker (MDA) in kidney of CdCl2-treated animals. This is in accord with the previous reports proceeding $\mathrm{Cd}$ induced oxidative stress in rats (Renugadev and Prabu, 2010 and Virk et al., 2013). However, previous report by Reyes et al. (2013) denoted that Cd -mediated formation of free radicals causes various modifications to DNA bases, increased lipid peroxidation, and altered $\mathrm{Ca}^{2+}$ and sulfhydryl homeostasis. The authors added that Lipid peroxides, formed by the attack of radicals on polyunsaturated fatty acid residues of phospholipids, can further react with redox metals, finally producing mutagenic and carcinogenic malondialdehyde, 4hydroxynonenal, and other exocyclic DNA adduct. Also, the intoxication of Cd leads to enhanced lipid peroxidation and protein carbonylation and to decrease of supper oxide dismutase (SOD) activity and glutathione (GSH) levels (Gong et al., 2012). In the same line, Cd-MT complex induces oxidative stress by interaction of $\mathrm{Cd}$ with mitochondrial structures and causes renal damage (Bernard, 2004 and Klassen et al., 2004). Therefore, the determine deficiency of the major antioxidant systems could result the previous alteration in all cellular organelles their function.

The present results analysis indicated a decreased in total antioxidant capacity (TAC) enzymes following Cd treatment. This confirming the obtained increased MDA in kidney tissue besides means decrease in the endogenous antioxidant system like GSH, CAT, SOD, other macromolecules and small molecules activities toward neutralize ROS generated by $\mathrm{Cd}$ dose. The reduction of MDA might be due to combat this system in consumption of the scavenging the free radicals generated by cadmium (Nigam et al., 1999). Previous studies exhibited that exposure to Cd increases lipid peroxidation and causes inhibition of SOD activity indicating oxidative damage in liver, kidney and testes (Patra et al., 1999).

In combined Cd and PPE treated animals in this work, an improvement in the kidney was observed. The results 
were in agreement with data obtained by Otunctemur et al., (2015) who reported that pomegranate extract attenuates structural and functional alterations in the kidney caused by unilateral ureteral obstruction, depressed the concentration of the cytokines and increased the antioxidative capacity. Kalangottil et al. (2014) revealed that the hydro-alcoholic extract of Punica granatum peel possessed inhibitory activity against ulcerative colitis. Moghaddam et al. (2013) reported that oral pretreatment with peel extracts with 25, $50 \mathrm{mg} / \mathrm{kg}$ for 15 days protected the gastric mucosa against the damage induced by indomethacin.

Pomegranate peel extract indicated an improving effect on the renal parenchyma in $\mathrm{CdCl}_{2}$ treated kidney, restored glomerular tuft, renal tubular epithelial cells destruction. These results are similar to that observed by Ali, and Saeed (2012) who found that aqueous extract of Punica granatum modified all histological alterations in gentamicin-induced renal toxicity in rats. Moreover, Abdel Moneim et al. (2013) indicated that the methanolic extract of pomegranate peel could able to inhibit Al-induced oxidative stress and alternations in liver and kidney of female rats that related to anti-apoptotic and antioxidant activities. Other correlation between the role of pomegranate peel extract and regulating vital cellular functions, including cell proliferation and differentiation as well as its potent antioxidant activity and free radical scavenging capability was reported by Mastrodi Salgado (2012) and Ismail et al. (2012). Other studies have shown that pomegranate is a potent anticancer agent that causes inhibition of multiple signaling pathways in cancer cells, inhibition of tumorigenesis in animal models of various carcinomas and inhibiting cell cycle progression (Nair et al., 2011).

Therefore, the cell apoptosis indicated by high expression of Bcl-2 and $\alpha$-SMA in Cd group in the present study was lowered after co-administration of pomegranate peel extract might be linked to its ability to regulate the expression and activity of cell cycle-related proteins. Another suggestion is that PPE may regulate the disturbances of ER calcium homeostasis that involved in the pathologic process leading to ischemic cell injury.

Moreover, the chemopreventive activity of pomegranate on kidney against Cd toxicity could relate to its antioxidant activity to retard the synthesis of metalothionin in the liver or kidneys. Indeed, pomegranate is superior in protecting low-density lipoprotein "the bad cholesterol" and high-density lipoprotein "the good cholesterol" from oxidation (Aviram and Rosenblatreported, 2013) and inhibitors of LPO, production of nitric oxide (NO), and inducible nitric oxide synthase activity in different model systems (Aviram et al.,2002). Furthermore, PPE extract prevent nephrotoxicity by neutralize oxidative stress and lipid peroxidation through scavenging ROS, increasing certain antioxidant enzyme activities, inducing metal chelation activity and inhibiting or activating certain transcriptional factors. Consistent with this observation, the pomegranate emulsion suppressed several inflammatory markers including NO synthase, COX-2, and NF- $\kappa \mathrm{B}$ induced in rats following exposure to diethylnitrosamine (Bishayee et al., 2013).
Also, presence of polyphenols that pharmacological known as antioxidant properties as it responsible for antioxidants, anti-inflammatory, anti-mutagenic, anti-carcinogenic and antimicrobial effects (Ismail et al., 2012).

The present biochemical results showing that coadministration of pomegranate peel extract to animals treated with Cd significantly decreased the serum urea, creatinine and BNU compared with Cd treated group. This is in agreement with Albasha and Azab (2016) who found that co-treatment of aqueous extract of pomegranate (Punica granatum) to nicotine treated male Guinea pigs diminished these parameters. Sadeghi et al., (2015) reported that $25 \mathrm{mg} / \mathrm{kg}$ pomegranate flower extract decreased the serum levels of creatinine and blood urea nitrogen after gentamicin treatment.

The present study reduction in MAD level following $\mathrm{CdCl} 2$ with PPE treated animals in compared with $\mathrm{CdCl}_{2}$ treated group. This is providing a decrease of lipid peroxidation in the tissue. In this respect Otunctemur et al., 2015 reported that the excessive MDA produced as a result of tissue injury and DNA damage could combine with free amino groups of proteins, resulting in the formation of MDA-modified protein adducts.

The decreased MAD level in $\mathrm{CdCl}_{2}$ with PPE treated animals was confirmed by increased of TAC level in tissue of the same group. This indicated that PPE play important role in the increase the protective mechanism through the natural antioxidant enzymes in cells and free radical scavenger against the oxidative stress induced by $\mathrm{Cd}$. Moreover, this finding strongly indicates that PPE can participate in the elimination of oxygen free radicals and lipid peroxidation after Cd-induced kidney through apoptosis and the necrosis. This is in agreement with Aboonabi et al. (2014) who found that pomegranate can increase antioxidant enzyme, which has ability to ameliorate oxidative stress, and protects the hepatic and renal tissues in diabetic rats. Also, Sies (2007) reported that large increases in the TAC of plasma have been observed after the consumption of flavonoid-rich foods by humans as play an important role as antioxidants in vivo, thereby decreasing chronic disease risk.

It was concluded that, $\mathrm{Cd}$ had adverse effects on the kidney structure and function parameters in the blood serum. PPE administration showed a remarkable amelioration of abnormalities related Cd-nephrotoxicity and enhanced the detoxification process in mice. It may deliver defense by reducing the concentration of oxidant products by scavenging free radicals associate the total antioxidant capacity. Advance studies are essential to clarify exact mechanism of renal protection through its active constituents as a protective agent in clinical trials.

\section{References}

Aboonabi, A., Rahmat, A. and Othman, F. (2014). Effect of Pomegranate on Histopathology of Liver and Kidney on Generated Oxidative Stress Diabetic Induced Rats. J. Cytol. Histol., (6): 294.

Abdel-Moneim, A.E.; Othman, M.S.; Mohmoud, S.M. and El-Deib, K.M.(2013). Pomegranate peel 
attenuates aluminum-induced hepatorenal toxicity. Toxicol. Mech. Methods., 23(8):624-33.

Afaq, F.; Khan, N.; Syed, D. N. and Mukhtar, H. (2010).Oral feeding of pomegranate fruit extract inhibits early biomarkers of UVB radiation-induced carcinogenesis in SKH-1 hairless mouse epidermis. Photochem. Photobiol., 86 (6):1318-1326.

Albasha, M. O. and Azab, A. E. (2016). Hepatorenal Protective Effects of Pomegranate (Punica granatum) Juice against Nicotine Induced Toxicity in Guinea Pigs. J. Advan. Biol. \& Biotechnol., JABB, 5(1): 1-13.

Ali, T. H.(2012). Determination of the lethal dose $50 \%$ (LD50) of cadmium chloride and the histopathological changes in male mice liver and kidneys. J. Edu. \& Sci., 25(3): 27- 38.

Ali, N.A.M. and Saeed, S.Z. (2012). Nephroprotective effect of Punica granatum in gentamicininduced nephrotoxicity in rats. Med. J. Babylon., 9(1):220228.

Al Olayan, E.M.; El Khadragy, M.F.; Metwally, D.M. and Abdel Moneim, A.E. (2014). Protective effects of pomegranate (Punica granatum) juice on testes against carbon tetrachloride intoxication in rats. BMC Compl. Alter Med., (14):164:1-9.

Aviram, M.; Dornfeld L, Kaplan M.; Coleman, R.; Gaitini, D. and Nitecki, S. (2002). Pomegranate juice flavonoids inhibit low-density lipoprotein oxidation and cardiovascular diseases: studies in atherosclerotic mice and in humans. Drugs Exp Clin Res., (28):49-62.

Aviram, M. and Rosenblat, M. (2012). Pomegranate protection against cardiovascular diseases. Evidence Based Complementary and Alternative Medicine, vol. 2012, Article ID 382763, 20 pages.

Banchroft, J.D.; Stevens, A. and Turner, D.R.(1996). Theory and Practice of Histological Techniques. $4^{\text {th }}$ ed., New York, London, San Francisco, Tokyo, Churchill Livingstone.

Benbrahim-Tallaa, L.; Tokar, E.J.; Diwan, B.E.; Dill, A.L.; Coppin, J.F. and Waalkes, M.P.(2009). Cadmium malignantly transforms normal human breast epithelial cells into a basal-like phenotype. Environ. Health Perspect., (117): 1847-1852.

Bernard, A. (2004). Renal dysfunction induced by cadmium: biomarkers of critical effects. Biometals, (17):519-23.

Berridge, M. J. (2012): Calcium signaling remodeling and disease, Biochem.Soc. Trans. (40) : 297309.

Bishayee, A.; Thoppil, R.J.; Darvesh, A.S.; Ohanyan, V.; Meszaros, J.G. and Bhatia, D. (2013). Pomegranate phytoconstituents blunt the inflammatory cascade in a chemically induced rodent model of hepatocellular carcinogenesis. J Nutrit. Biochem., 24( 1):178-187.

Buser, M.C., Ingber, S.Z., Raines, N., Fowler, D.A., Scinicariello, F.(2016). Urinary and blood cadmium and lead and kidney function: NHANES 2007-2012. Int J Hyg Environ Health. 219(3):261-7. .
Carey, A.V.; Carey, R.M. and Gomez, R.A. (1992). Expression of alpha-smooth muscle actin in the developing kidney vasculature. Supplement II Hypertension, 19(2): 168-175.

Chen, W.C.; Chen, H.Y.; Wu, H.C.; Wu, M.C.; Hsu, C.D. and Tsai, F.J. (2003).Vascular endothelial growth factor gene polymorphism is associated with calcium oxalate stone disease. Urol. Res., 31:218-22.

Colombo, E.; Sangiovanni, E. and Dell'agli, M. (2013). A review on the anti-inflammatory activity of pomegranate in the gastrointestinal tract. Evidence Based Complementary and Alternative Medicine, vol. 2013, Article ID 247145, 11 pages.

Duchen,M.R. (2000). Topical Review, Mitochondria and calcium: from cell signalling to cell death. J. Physiol., 529 (1): 57-68.

El-Boshy, M. E.; Risha, E. F.; Abdelhamid, F. M.; Mubarak, M. S. and Hadda, T. B. (2015). Protective effects of selenium against cadmium induced hematological disturbances, immunosuppressive, oxidative stress and hepatorenal damage in rats. J. Trace Elem. Med. Biol., (29):104-110.

El-Morsy, A.M., Sakr, S.A., and Bayomy, M.F (2015). Ameliorative effect of aqueous leaves extract of Rosemarinus officinalis on cadmium - induced kidney injury in albino rats. J. Biosci. \& Appl. Res., 1(1):10-19.

El-Refaiy, A. and Eissa, I. F. (2013): Histopathology and cytotoxicity as biomarkers in treated rats with cadmium and some therapeutic agents. Saudi J. Biol. Sci., (20): 265-280.

El-Toumy S A and Rauwald H.(2002). Two ellagitannins from Punica granatun heartwood. Phytochem., (61): 971-974.

Gaurav, D.; Preet, S. and Dua. K.K. (2011). Protective influence of dietary nutrients on antioxidant defense system in the blood of rats treated with cadmium. Adv. Appl. Sci. Res., 2(2): 69-78.

Galal-Gorchev, H. (1993). Dietary intake, levels in food and estimated intake of lead, cadmium and mercury. Food Add. Contam., (10):115-128.

Gobe, G.; Rubin, M. and Williamns, G. (2002). Apoptosis and expression of Bcl-2, Bcl-XL and Bax in renal cell carcinoma. Cancer Invest., 20 (3):324-332.

Gong, P., F.; Chen, X.; Liu, X.; Gong, J.; Wang, J. and Ma, Y. (2012). Protective effect of caffeic acid phenethyl ester against cadmium induced renal damage in mice. J. Toxicol. Sci., 37(2): 415-425.

Görlach,A.; Bertram, K.; Hudecova, S. and Krizanova, O. (2015). Calcium and ROS: A mutual interplay. Redox Biol., (6): 260-271

Gross, A.; Jockel, J.; Wei, M.C. and Korsmeyer, S.J. (1998). Enforced dimerization of Bax results in its translocation, mitochondrial dysfunction and apoptosis. EMBO J. (17): 3878 - 3885.

Hsu, Y.T and Youle, R.J. (1998). Bax in murine thymus is a soluble monomeric protein that displays differential detergent-induced conformations. J. Biol. Chem., (273): 10777 -10783. 
Hugo, C.; Pichler, R.; Gordon, K.; Schmid,T. R.; reduced pyridine nucleotides. Cell Death Differ., (7): 903Amieva, M.; Couser, W. G.; Furthmayr, H. and Johnson, 910.

R.J.(1996). The cytoskeletal linking proteins,

moesin and radixin, are upregulated by plateletderived growth factor, but not basic fibroblast growth factor in experimental mesangial proliferative glomerulonephritis. J. Clin Invest., (97): 2499 -2508.

Hussain, B. I. and AL-Taee, N. H. (2014). Ameliorated effect of green tea extract on cadmium toxicity in liver and kidney of rats. J Babylon Univer. Pure Appl. Sci., 6 (22): 1746-1753.

Ignarro, L.J.; Byrns, R.E.; Sumi, D.; Nigris, F.D. and Napoli, C. (2006). Pomegranate Juice Protects Nitric Oxide against Oxidative Destruction and Enhances the Biological Actions of Nitric Oxide. Nitric Oxide, (15): 93-102.

Ismail, T.; Sestili , P. and Akhtar, S. (2012). Pomegranate peel and fruit extracts: a review of potential anti-inflammatory and anti-infective effects. J. Ethnopharmacol. , 143(2):397-405.

Itoh, Y., Yasui., T.; Okada, A.; Tozawa, K.; Hayashi, Y. and Kohri, K. (2005).Preventive effects of green tea on renal stone formation and the role of oxidative stress in nephrolithiasis. J. Urol., (173):271-5.

Itoh, H.; Iwasaki, M.; Sawada, N.; Takachi, R.; Kasuga Y.; Yokoyama, S.; Onuma, H.; Nishimura, H.; Kusama, R. andYokoyama, K. (2014). Dietary cadmium intake and breast cancer risk in Japanese women: A casecontrol study. Int. J. Hyg. Environ. Health; Health, (217): 70-77

Jain,V.; Viswanatha, G.L.; Manohar, D. and Shivaprasad, H. N.(2012): Isolation of antidiabetic principle from fruit rinds of Punica granatum. EvidenceBased Complementary and Alternative Medicine,. 2012: 111

Jarup, L. (2002). Cadmium overload and toxicity. Nephrol. Dialysis Transplant., 17(2): 35-39.

Johri , N.; Jacquillet,G. and Unwin, R. (2010): Heavy metal poisoning: the effects of cadmium on the kidney. Biometals, (23):783-92.

Koyu, A.; Gokcimen, A.; Ozguner, F.; Bayram, D.S. and Kocak, A. (2006). Evaluation of the effects of cadmium on rat liver. Mol. Cell Biochem., (20): 1-5.

Kalangottil, A.; Hegde, K. and Naseeb, K. M. (2014). Evaluation of Protective Effect of Hydro-alcoholic Extract of Fruit Peels of Punica granatum Linn against Ulcerative Colitis in Rats. Int. J. Pharm. Sci. Drug Res., 6(3): 211-215.

Klassen, R. B, Crenshaw, K. and Kozyraki R. (2004). Megalin mediates renal uptake of heavy metal metallothionein complexes. Amer. J. Physiol., 287(3):393403.

Koriem, K.M.; Arbid, M.S. and Asaad, G.F. (2013). Chelidoniummajus leaves methanol extract and its chelidonine alkaloid ingredient reduces cadmium-induced nephrotoxicity in rats. J. Nat. Med., 67(1): 159-167.

Kowaltowski, A. J.; Vercesi, A. E. and Fiskum, G. (2000). Bcl-2 prevents mitochondrial permeability transition and cytochrome $\mathrm{c}$ release via maintenance of
Lafuente, A.; Marquez, N.; Perez-Lorenzo, M.; Pazo, D. and Esquifino, A. I. (2000). Pubertal and postpubertal cadmium exposure differentially affects the hypothalamicpituitary-testicular axis function in the rat. Food Chem Toxicol., (38): 913-923.

Llobet, J.M. ; Granero, S. ; Torres, A. ; Schuhmacher, M. and Domingo, J.L. (1998). Biological monitoring of environmental pollution and human exposure to metals in Tarragona, Spain III. Blood levels. Trace Elem Electr (15): 76- 80.

Madeddu, R.; Tolu, P.; Asara, Y.; Farace, C.; Forte, G. and Bocca, B.(2012). Blood biomonitoring of metals in subjects living near abandoned mining and active industrial areas. Environ. Monit. Assess., (185): 5837-5846.

Mahran, A.A.; Husam Eldien, H.O.; Abd El-Mawla, A.M.A. and Attia ,A.M. (2011). Protective Effect of Zinc (Zn) on the Histology and Histochemistry of Liver and Kidney of Albino Rat Treated with Cadmium. J. Cytol. Histol., 2(4): 1-9.

Moghaddam,G.; Sharifzadeh,M.; Hassanzadeh, G.; Khanavi M. and Hajimahmoodi, M.(2013).AntiUlcerogenic Activity of the Pomegranate Peel (Punica granatum) Methanol Extract Food and Nutrition Sci., (4): 43-48

Mastrodi Salgado, J. ; Baroni Ferreira , T.R., de Oliveira Biazotto, F. and Dos Santos Dias, C.T. (2012). Increased antioxidant content in juice enriched with dried extract of pomegranate (Punica granatum) peel. Plant Foods Hum. Nutr. Mar., 67(1):39-43.

Mohammad, S. I.; Mustafa, I. A. and. Abdulqader, S. Z. (2013).Ameliorative Effect of the Aqueous Extract of Zingiber officinale on the Cadmium-Induced Liver and Kidney Injury in Females Rats. Jordan Journal of Biological Sci., 6(3):231-234

Murphy, A. N.; Bredesen, D. E.; Cortopassi, G.; Wang, E. and Fiskum, G. (1996).Bcl-2 potentiates the maximal calcium uptake capacity of neural cell mitochondria. Proc. Natl . Acad. Sci., (93): 9893-9898.

Nagata, C.; Nagao, Y.; Nakamura, K.V.; Wada, K.V.; Tamai, Y.; Tsuji, M.; Yamamoto, S. and Kashiki, Y.(2013).Cadmium exposure and the risk of breast cancer in Japanese women. Breast Cancer Res. Treat. , (138): 235239.

Nair, V.; Dai, Z.; Khan, M. and Ciolino, H.P. (2011). Pomegranate Extract Induces Cell Cycle Arrest and Alters Cellular Phenotype of Human Pancreatic Cancer Cells. Anticancer Res., (31): 2699-2704.

National Research Council (NRC) (1985). Guide f or use and care of lab oratory animals. $\mathrm{N}$ ational $\mathrm{R}$ esearch Council, Publication No. 85-23, NIH, W ashington.

Nigam, D.; Shukla, G. S. and Agarwal, A. K. (1999). Glutathione depletion and oxidative damage in mitochondria following exposure to cadmium in rat liver and kidney. Toxicol. Lett., (106): 151-157.

Nordberg, G.; Jin, T.; Bernard, A.; Fierens, S.; Buchet, J.P.; Ye, T.; Kong, Q. and Wang, H. (2002). Low bone density and renal dysfunction following 
environmental cadmium exposure in China. Ambio.; (31): 478-481.

Orrenius , S.; Zhivotovsky, B. and Nicotera, O. (2003). regulation of cell death: the calcium-apoptosis link. Nature Reviews, Molec. Cell boil., (4):552-565.

Otunctemur A. ; Ozbek, E.; Cakir, S. S.; Polat, E. C.; Dursun, M,; Cekmen M.; Somay, A. and Ozbay, N.(2015).Pomegranate extract attenuates unilateral ureteral obstruction-induced renal damage by reducing oxidative stress. Urol Ann., 7(2): 166-171. doi: 10.4103/09747796.150488

Ozbek, E.; Ilbey, Y.O.; Ozbek, M.; Simsek, A.; Cekmen, M. and Somay, A. (2009). Melatonin attenuates unilateral ureteral obstruction-induced renal injury by reducing oxidative stress, iNOS, MAPK, and NF-kB expression. J. Endourol., (23):1165-73.

Patra, R.C.; Swarup, D. and Senapati, S.K. (1999). Effects of cadmium on lipid peroxides and superoxide dismutase in hepatic, renal and testicular tissue of rats. Vet. Hum. Toxicol., (41):65-67.

Pezzella, F.; Tse, A.; Cordell, J.L.; Pulford, K.A.F.; Gatter, K.C. and Mason, D.Y. (1990). Expression of the bcl-2 oncogene protein is not specific for the $14 ; 18$ chromosomal translocation. Am. J. Pathol., (137):225-232.

Renugadevi, J. and Prabu, S.M. (2010). Quercetin protects against oxidative stress-related renal dysfunction by cadmium in rats. Exp. Toxicol. Pathol., 62(5): 471-481.

Reyes, J. L.; Molina-Jijón,E.; Rodríguez-Muñoz, R.; Bautista-García,P.; Debray-García,Y.; and Carmen Namorado, M. D.(2013). Tight Junction Proteins and Oxidative Stress in Heavy Metals-Induced Nephrotoxicity. BioMed Research International Volume 2013, Article ID 730789, 14 pages http://dx.doi.org/10.1155/2013/730789

Robertson, J. D.; Orrenius, S. and Zhivotovsky, B. (2000). Nuclear events in apoptosis. J. Struct. Biol., (129): 346-358.

Ruiz-Larrea, M. B.; Leal, A. M.; Liza, M.; Lacort, M. and de Groot, H. (1994). Antioxidant effects of estradiol and 2-hydroxyestradiol on iron-induced lipid peroxidation of rat liver microsomes. Steroids, (59): 383-388.

Sadeghi, F., Nematbakhsh, M.; Noori-Diziche, A.; Eshraghi-Jazi, F.; Talebi, A.; Nasri, H.; Mansouri, A.; Dehghani, A.; Saberi, S.; Shirdavani, S. and Ashrafi, F. (2015). Protective effect of pomegranate flower extract against gentamicin-induced renal toxicity in male rats. J Renal Inj Prev., 4(2): 45-50.

Selvam, R. (2000). Calcium oxalate stone disease: role of lipid peroxidation and antioxidants. Urol. Res., (30):35-47.

Schöpfer, J.; Drasch, G. and Schrauzer, G.N. (2010). Selenium and cadmium levels and ratios in prostates, livers, and kidneys of nonsmokers and smokers. Biol. Trace Elem. Res., (134): 180-187.

Siddiqui, M.F. (2010). Cadmium induced renal toxicity in male rats, Rattus rattus. Eastern Journal of Medicine (15):93-96.
Sies, H. (2007). Total Antioxidant Capacity: Appraisal of a Concept1,2 J. Nutr. .(137): 1493-1495.

Stephenson, L.A.;Haney, L B.;Hussaini, I M.; Karns, L R. and Glass II, W F. (1998). Regulation of smooth muscle a-actin expression and hypertrophy in cultured mesangial cells. Kidney International, (54):1175-1187.

Tellez-Plaza, M.; Navas-Acien, A.; Crainiceanu, C.M. and Guallar, E.(2008). Cadmium exposure and hypertension in the 1999-2004 National Health and Nutrition Examination Survey (NHANES). Environ. Health Perspect., (116): 51-56.

Templeton, D. M. and Liu,Y. (2013).Effects of cadmium on the actin cytoskeleton in renal mesangial cells. Canad. J..Physiol. Pharmacol., 91(1): 1-7.

Tsuda ,T.; Horio, F. and Osawa, T. (2002). Cyanidin 3-O-beta-D-glucoside suppresses nitric oxide production during a zymosan treatment in rats. J. Nutr. Sci.Vitaminol (Tokyo), (48):305-10.

Viladomiu, M.; Hontecillas,R.; Lu, P. and Bassaganya- Riera, J.(2013). Preventive and prophylactic mechanisms of action of pomegranate bioactive constituents. Evidence Based Complementary and Alternative Medicine, vol. 2013,Article ID 789764, 18 pages.

Virk, P.; Elobeid, M.; Hamad, S.; Korany, Z.; AlAmin, M.; Daghestani, M.;

Omer, S.; AlOlayan, E.; Siddiqui, M.I. and Mirghani, N.M. (2013). Ameliorative effects of Embilica officinalis and Rosmarinus officinalis on cadmium-induced oxidative stress in Wistar rats. J. Med.. Plant Res., 7(14): 805-818.

Waalkes, M.P. (2003). Cadmium carcinogenesis. Mutat. Res. (533): 107-120.

Waisberg, M.; Joseph, P.; Hale, B. and Beyersmann,D. (2003): Molecular and cellular mechanisms of cadmium carcinogenesis: a review. Toxicol.; (192): 95-117.

Young, D.S. and Friedman, R.B. (2001).Effects of Disease on Clinical Laboratory. Testes, $4^{\text {th }}$ ed. AACC press, Washington, USA.

Yuan, Ya; Bian, J. C. and Liu, X.Z. (2012).Oxidative Stress and Apoptotic Changes of Rat Cerebral Cortical Neurons Exposed to Cadmium in Vitro. Biomed Environ Sci., 25(2):172-181.

Zarfeshany, A.; Asgary, S. and Javanmard, S.H. (2014). Potent health effects of pomegranate. Adv. Biomed. Res., 3(100):1-8.

Zhou, Z.; Wang, C.; Liu, H.; Huang, Q.; Wang, M. and Lei ,Y. (2013). Cadmium Induced Cell Apoptosis, DNA Damage, Decreased DNA Repair Capacity, and Genomic Instability during Malignant Transformation of Human Bronchial Epithelial Cells. Int. J. Med. Sci., 10(11):1485-149 